by leaders of the Knowledge Is Power Program (KIPP) and the Harlem Children's Zone. Today, more than ever, Spencer says, we need to realize that schools cannot improve themselves by themselves, and that teachers and administrators alone cannot guarantee equal opportunity. We need to recognize, as Foster did, the importance of the "total school community."

Luther Spoehr

Brown University

\title{
Rychetta Watkins, Black Power, Yellow Power, and the Making of Revolutionary Identities (Jackson: University Press of Mississippi, 2012).
}

Rychetta Watkins' Black Power, Yellow Power, and the Making of Revolutionary Identities offers a cultural history of African American and Asian American "indigenization" of anti-colonial politics from the late 1960s through the early 1980s. Taking seriously the paradigm of "power," Watkins examines the politics of selfdetermination and self-representation among racialized groups in the U.S. as they evoked and interpreted global decolonizing movements in the aftermath of Bandung. Black Power, Yellow Power begins with a chapter on how African and Asian American activists interpreted Franz Fanon's writings. It then highlights the importance of the "guerilla" figure in defining the political, intellectual, and cultural subjectivities of black and Asian American activists, academics, and cultural producers. Seeking to contribute to an emerging field of Afro Asian studies, Watkins examines how African and Asian political influences and writings inspired the imagination and shaped the subjectivity of African Americans and Asian Americans. In some instances, Watkins also examines how these racialized groups politically inspired one another, although this mentorship mainly flowed from African American instructors to Asian American political pupils.

Watkins is a literary and cultural studies scholar who is interested in the historical emergence and transmission of political ideas and subjectivities. Her study raises intriguing interpretations and unearths important cross-racial and transnational connections. However, not all of the claims in the book are thoroughly developed, and the decision to focus on particular time periods, topics, sources, and writers, is not always substantiated.

For example, Watkins posits the period of the mid-to-late 1960s to the early 1980s as an era of power politics. This chronology is only briefly defined and justified. The period begins with Stokely Carmichael's use of the phrase "black power," and it ends with Elaine Brown stepping down as chair of the Black Panther Party. I appreciate Watkins' efforts to conceptualize a "long” black power political movement, but I wanted more evidence as to why this time period should be treated as a cohesive era. Aside from the publication dates of the works that Watkins is analyzing, what political developments were occurring to 
demarcate this time period as a black power period?

Watkins' chronology also gives uneven attention to the category of "yellow power." One of the goals of Black Power, Yellow Power is to foreground the concept of "yellow power." Watkins analyzes its origins in the late 1960s. However, she does not address the evolution of this concept. According to sociologist Yen Le Espiritu, the phrase "yellow power" quickly gave way to the category of Asian American, because the former did not acknowledge and include the experiences of Filipinos who identified themselves as "brown" rather than yellow. There also is little discussion of when yellow power ends in Watkins' work. The publication of important Asian American writings in the late 1970s seems to be important markers for Watkins. However, what was occurring politically and culturally during this era and how does it change in the early 1980s?

Watkins' formulation of the importance of the guerilla figure in black and yellow power is a particularly intriguing contribution of this book. Her interpretation is based on reading movement publications, such as The Black Panther Newspaper and Gidra, an Asian American publication based in Los Angeles. Watkins illuminates the evolution and usage of the guerrilla icon as a revolutionary and oppositionist role model, which helped form the political subjectivity of African and Asian Americans, particularly men. Watkins is interested in recuperating the political potential of the power politics era from subsequent criticisms, including critiques of the masculinist bias of cultural or revolutionary nationalism. Consequently, it is surprising that Watkins did not analyze or discuss the representations of female guerillas that also appeared in The Black Panther and Gidra. These images commonly depicted Asian, Middle Eastern, and African female revolutionaries, often with AK-47s in one hand and babies in another. Watkins missed an important opportunity to complicate the gendered representations of nationalism and internationalism that were being circulated in black and Asian American activist publications.

In addition to this striking omission, Watkins' choice of authors for her comparative literary analysis is at times puzzling. The relationship between Ishmael Reed and Frank Chin is interesting, particularly given Reed's commitment to promoting multi-racial literature and his role in publishing an important Asian American literary anthology that Frank co-edited, AIIIEEEEE! However, the connection between Sam Greenlee's The Spook Who Sat by the Door, John Okada's No-No Boy, and Alice Walker's Meridian is less easily discerned. Watkins argues that they all address issues of self-determination and racial consciousness but illustrate "the violent nihilism and empty spectacle that lurks within the guerrilla identity, especially when detached from its particular political milieu" (115116). This theme is not wholly satisfying, especially since Okada's book was initially published in 1957, before the power movement and the fascination with Vietnamese anti-colonial underdogs began. No-No Boy was republished in 1976, which suggests a desire to revisit the significance of the novel. However, the 
book focuses on World War II and its more immediate aftermath, not the Power movement era and its demise.

Black Power, Yellow Power, and the Making of Revolutionary Identities is a significant contribution to the scholarship on comparative racialization and political mobilization. It is primarily a suggestive work, though, that focuses on the transmission and interpretation of select "texts" and "ideas." A greater attention to social and historical contextualization as well as gender analysis could have strengthened the insights of this book.

Judy Tzu-Chun Wu

Ohio State University

\section{Nelson Lichtenstein and Elizabeth Tandy Shermer, eds. The Right and Labor in America: Politics, Ideology, and Imagination (Philadelphia: University of Pennsylvania Press, 2012).}

While historians have spilled much ink recounting in detail the violence and political attacks that anti-union forces have visited upon labor and its supporters, it is only in recent years that they have turned their attention to studying those anti-union forces themselves. Understanding how and why these movements developed is essential for understanding labor's decline and the rightward political shift in recent decades.

Lichtenstein and Shermer's edited volume, The Right and Labor in America, is a welcome addition to this body of work. Over fourteen wide-ranging chapters, the contributors show how anti-unionism is not merely an issue that many U.S. conservatives have championed in the twentieth century. Rather, "hostility to trade unionism per se was a crystallizing impulse for the modern American conservative movement" (8).

Many of the chapters focus on the development of modern conservatism's "rhetoric of reaction," to use Hirschman's apt expression. From the evolution of "free trade," to the cry for "states' rights," to the development of "humanist" management, to the emergence of the "right to work" movement, conservative activists and intellectuals mobilized around powerful national tropes of rights and freedom.

But the articulation of such tropes, and their mobilization in the service of right-wing causes, was far from a smooth and inevitable process. As many of the authors show, it was often contingent and riven with conflict. Take for example Michael Pierce's fascinating study of the political evolution of Arkansas Governor Orval Faubus. While he is primarily known today for his stand against racial integration at Little Rock Central High School, Faubus began his political life steeped in a rural Ozark socialist tradition, and was initially elected with the support of a bi-racial, labor-backed coalition. However, with the rise of "massive 